\title{
A SURVEY OF ISOETES COROMANDELINA L. F. POPULATIONS IN TIRUNELVELI DISTRICT
}

\author{
Sahaya Anthony Xavier, G*., S. Sundhari, P. Mariammal, M. Vaishnavi and T. Vanitha \\ Department of Botany, St. Xavier's College (Autonomous), Palayamkottai - 627002. \\ *E.mail: saxsxc@gmail.com
}

\begin{abstract}
The genus Isoetes is a cosmopolitan genus found around the world. The genus consists of aquatic or semi-aquatic plants needing water for survival. The distribution of Isoetes coromandelina $\mathrm{L}$. $\mathrm{f}$. in the freshwater ponds of Tirunelveli district was studied. The results of the survey show that the population of Isoetes coromandelina in Tirunelveli district are healthy and flourish wherever non-polluted, nutrient poor waters are available. Although there is no danger to the populations of Isoetes at present, water pollution could endanger the survival of the species.
\end{abstract}

Keywords: Isoetes coromandelina, survey, Tirunelveli, cosmopolitan genus.

\section{INTRODUCTION}

Isoetes L. is a cosmopolitan genus of heterosporous lycopsids comprising approximately 150 species found in lakes, wetlands (swamps, marshes), and terrestrial habitats (Taylor et al., 1993) all over the world. 16 species of Isoetes have been reported from different geographical regions of India. Most of the populations are found growing along the margins of small ditches and ponds (Srivastava et al., 1993).

Around the world, the genus Isoetes is facing a lot of issues that affect its survival due to loss of habitat, an increase in agricultural land use, and invasion of exotic species. Isoetes has been declared an endangered species in Korea (Changkyun et al ., 2008). In China all the four species present face extinction due to habitat loss, agricultural land use and invasion by exotic species (Fu and Jin, 1992). Local populations of I. coreana in Korea growing in marshy areas close to farmland face intense competition from other hydrophytes such as Eriocaulon sieboldianum, Juncus effuses var. decipens Buchen, and Scirpus triangulates Roxb. As a result, I. coreana plants are now isolated and endangered in South Korea.

Isoetes is an aquatic / amphibious species. The requirement of a large amount of standing water is essential for the survival and reproduction of the species. Tirunelveli district falls in the rain shadow region of the southern Western Ghats. Consequently, while the western parts of the district may receive some rainfall and also some streams dot the countryside, as one moves to the eastern part of the district, the availability of freshwater decreases. The ponds near and east of Tirunelveli/ Palayamkottai depend on the water released from the dams. When the north-east monsoon fails, the ponds in the eastern parts of the district have been observed to be dry and without water for years together.

Though Isoetes cannot live without water, it has been observed to regrow vigorously once water is made available either through rain or by release from the dam. Could the survival of Isoetes during the rainfall deficient years be due to the perennating structures present in the soil? Could these also account for the rapid growth and colonization of large stretches of a pond's area once water is available?

This survey of Isoetes populations in Tirunelveli district aims to answer these questions. The study of the population, population distribution, population structure and genetic diversity of the populations is important to have an idea of the extent of the spread of the population and its genetic health. It will also help us to analyze and understand how the species is coping in the wild to environmental challenges and changes. Such knowledge can give us critical insights and knowledge into the adaptive response of the species and the population as a whole to the stresses facing the populations. It would also help us to understand the long term risks facing the species and the steps needed to be taken to conserve the species. Therefore, this study was undertaken to survey and document the areas in Tirunelveli district where there are Isoetes coromandelina $\mathrm{L}$. f. populations 


\section{MATERIALS AND METHODS}

\subsection{Area of the study}

Tirunelveli District was taken as the area for the study. The Isoetes populations at the different sites were studied. The location of the study sites along with their latitude, longitude, altitude and ecological characteristics are given in Table 1.

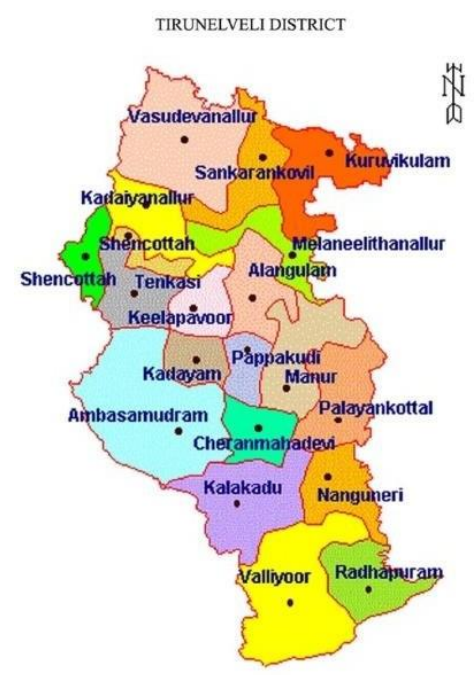

Fig. 1. Map of the study area

\subsection{Plant material}

Isoetes coromandelina L. f. was taken for study.

\subsection{Methods}

The study sites were inspected and the ecological characteristics noted. The plants were collected in the field. The GPS data was collected a Garmin 12XL device. Studies on the distribution of the Isoetes populations were conducted and noted. The study period was between November 2014 to March 2015.

\section{RESULTS AND DISCUSSION}

The characteristics of the different populations surveyed in Tirunelveli District are given in Table 1. Plate 1 shows the different habitats where Isoetes coromandelina grows in Tirunelveli District. The map of Tirunelveli District is given in Figure 1. A wide area with St. Xavier's College, Palayamkottai as the base has been surveyed. To the west, the plant populations along the Palayamkottai - Papanasam road up to Ambur railway gate have been surveyed. Along Ambur gate the populations have been surveyed up to Karuthapillaioor and then on to Alwarkurichi and further to Edaikal and then on to Palayamkottai. To the east, the Nanguneri Uvari road up to Uvari has been surveyed. A total of 18 populations have been surveyed. Due to constraints of time, some taluks in Tirunelveli district i.e. Kadayanallur, Vasudevanallur, Sankarankovil, Kuruvikulam, Shencottah and Melaneelithanallur could not be surveyed.

Table 1. List of Isoetes populations in Tirunelveli district surveyed in the current study.

\begin{tabular}{|c|c|c|c|c|c|}
\hline $\begin{array}{c}\text { S. } \\
\text { No }\end{array}$ & Location & Latitude & Longtitude & Altitude & Ecology \\
\hline 1 & $\begin{array}{l}\text { Cheranmahadevi } \\
\text { railway gate }\end{array}$ & \multicolumn{4}{|c|}{$\begin{array}{l}\text { N 8. 40.580 E } 7733.570202 \mathrm{ft} \text { This is a small population of Isoetes found } \\
\text { in a natural ditch near the railway gate. } \\
\text { The soil is a rich loamy reddish clay and } \\
\text { the plants are growing in a semi- } \\
\text { amphibious state. The growth of the } \\
\text { plants is not very vigourous and they are } \\
\text { very well spread out in the depression. }\end{array}$} \\
\hline 2 & Veeravanallur & N 8. 41. 026 & E 77. 31.714 & $228 \mathrm{ft}$ & $\begin{array}{l}\text { The Isoetes plants were found to be } \\
\text { growing in an irrigation channel filled } \\
\text { with rainwater in a semi-amphibious and } \\
\text { some plants were submerged in the } \\
\text { water. The plants in this area showed } \\
\text { vigourous growth. This may be because } \\
\text { of the soil which was clay soil with a lot of } \\
\text { humus present in it. The plants grew very } \\
\text { tall and formed a thick mat on the floor. } \\
\text { The population was intertwined with } \\
\text { many Marsilea plants. }\end{array}$ \\
\hline
\end{tabular}



Thadagam

4

South

Pappankulam -

Kallidaikurichi -

Manimuthar

Road

5

Kalllidaikurichi

Railway Station

6

Way to Ambur

Esakkiamam

7 Way to Ambur

Kulam

8 Puthuparaian

kulam
Temple Pond

N8.40.252 E 77.27.808

E7.27.808

N8.40.8 $01 \quad$ E77.28.039

255

N8.44.523 E77.24.880

E77.24.354

E77.23.645

342

N8.45.358

E77.23.645

konthankulam
9 Kaveri

N 8.45.425 E77.23.209

10 Achan kulam

Alwar kurichi

11 Vellikulam pottalputhur

N8.47.276

N8.47.605

E77.24.840
12

Idaikal kulam -

Adaichani

13 Kakkan Nagar

14 South

Vijayanarayanam

15 Tharuvai

N 8.671068

E 77.680560 -

16 Gopalasamudram

N 8.683392

E 77.644780 -

E 77.752503

E 77.763869 -

17 Veeravanallur

N 8.686786

E 77.524472 -
A small pool at the base of a hillock. The Isoetes are fringing the pool. Plants are separated and present like a fairies ring. Plants not clumped or dense in growth. Small population at the base of a hilling two small clumps. One clump has 40-50 plants and the second one has 7-10 plants.

Sand - red soil, stagnant pool, Isoetes -big population in an area $50 \times 20 \mathrm{~m}$, Isoetes plants at various stages forming a dense carpet at various places

Sand-red soil, big pond covered with Isoetes, huge population area50 $\times 50 \mathrm{~m}$ rimming the edges of the pond Sand - red soil, a pit on a sloping hillside, small population, Isoetes suppressed by angiosperm weed Big pond -small population seen near northern canal, population size $3 \mathrm{x} 5 \mathrm{ft}$, phenotypic differention in populations, population growing in water with tall individuals , population growing in soil with short individuals

A big pond with sandy soil dominated by Isoetes at its eastern edges, Isoetes present as beds approx. $10 \mathrm{~m}$ in width from edge of the pond, length of the Isoetes beds $>100 \mathrm{~m}$. Isoetes runs around the entire lake

Base of hill, gentle slope, red soil, tank is dry now, $15 \mathrm{~m}$ wide $\mathrm{x} 50 \mathrm{~m}$, present as a lush green mat in the process of drying. Base of excavated hill in pools of waterIsoetes found growing in water and all around the water's edge-plenty of algae for a thick mat on water-water has huge amount of humic content

Big pond sloping to south- Isoetes present on edge of the pond -red soil-clear water. On the Nanguneri - Uvari Road. Present as a lush green mat along the boundary of INS Vijayanarayanam base

The Isoetes plants grow along the sides of a local pond. The Isoetes plants would cover a few acres atleast fringing the rims of the pond. Very abundant.

A small population along the edges of the pond

A good population present near the local pond

A randomly dispersed population near the 
Police Station

18 Veeravanallur Petrol Bunk
N 8.687382 E 77.521569 police station

Sand red soil rich with humus. Stagnant water present in a natural depression. A small population present.

Plate 1. Isoetes coromandelina in different environments of Tirunelveli District.

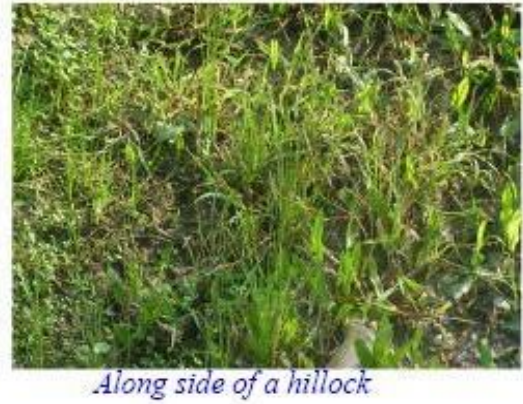

Along side of a hillock

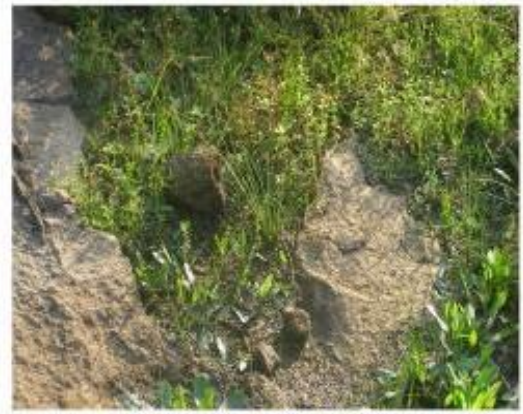

Growing anong rocks

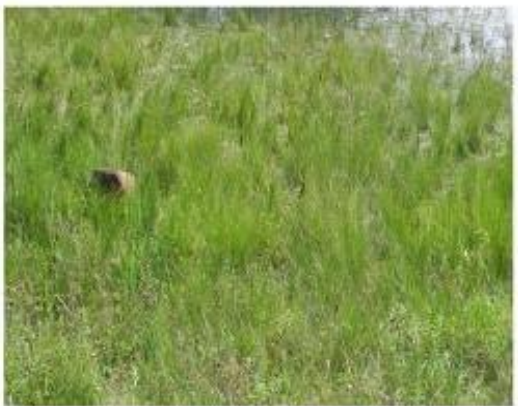

Growing on land and submerged

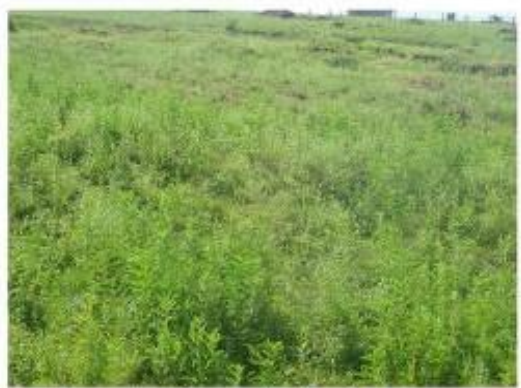

Growing along a hill side

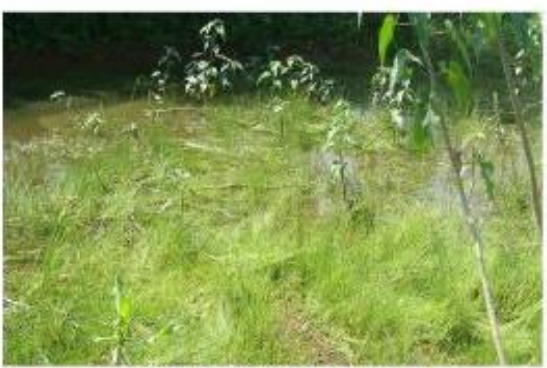

In a irrigation channel.

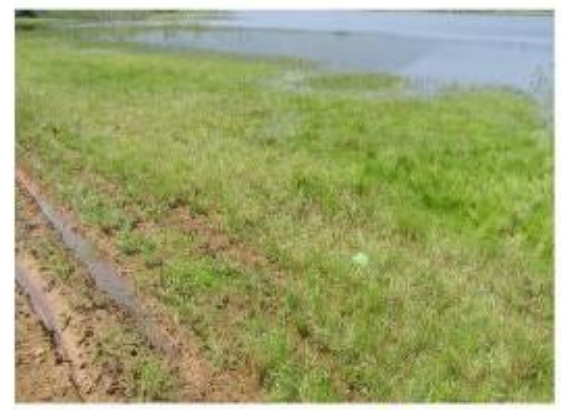

Growing along the edges of the pond.

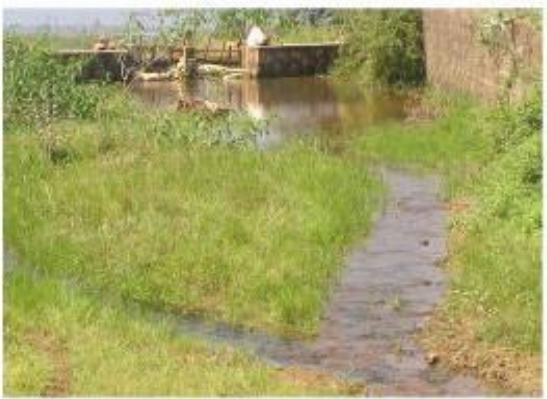

Growing in the irrigation channel.

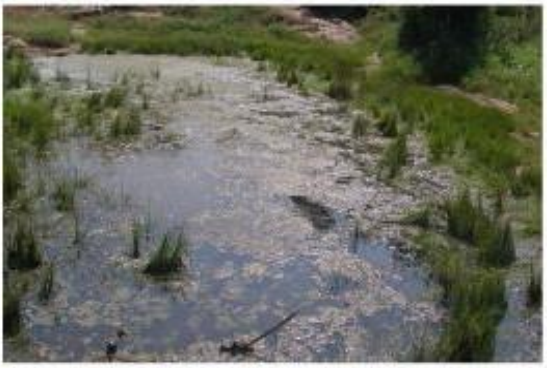

Growing in a stagnant pool of water: 
18 populations of Isoetes have been surveyed in this study. This study establishes that at the sites investigated i.e. fresh water ponds with an abundant supply of water, there are thriving populations of Isoetes. It also seems to suggest that a clean environment with oligotrophic waters is essential for the continued growth and survival of Isoetes.

At many sites such as Veeravanallur, Kallidaikurichy Railway Station, Ambur Esakkiamman Temple Pond, Puthuparaiyankulam, Kaverikoonthankulam, Achan Kulam, Vellikulam, Kakkan Nagar, South Vijayanarayanam the populations of Isoetes were well established and covered a huge area. At Pappankulam and Veeravanallur Thadagam the populations were very small. In fact, it seems that the population at Pappankulam could be either a newly established population or an old population which was on its way to disappearance locally. At Puthuparayankulam, the lush growth of Isoetes was seen. Further, it was seen that some of the Isoetes grew in the water while some grew away from the water on higher ground.

It has been reported by Sand - Jensen and Sondergaard (1979) that the quillwort I. lacustris, a submerged evergreen perennial, inhabits mainly nutrient - poor lakes. This is confirmed by Boston and Adams (1987) in their study of Isoetes. Quilloworts have evolved various adaptations to infertile habitats, including CAM metabolism (Keeley and Busch, 1984), high root biomass and slow leaf turnover (Boston and Adams, 1987; Gacia and Ballesteros, 1994). The adaptation to infertile habitats could explain the abundance of Isoetes in nutrient poor freshwater lakes.

\section{CONCLUSION}

A survey of the populations of Isoetes coromandelina in Tirunelveli district has been undertaken. The district received copious rain during 2014 - 15 due to which the ponds were full to the brim either with the rainwater or the water released from the dams. This has helped the growth of Isoetes. The growth of Isoetes was observed in ponds that had been dry for many years.

Though Isoetes cannot survive without water, the species has demonstrated its ability to recover and establish itself when water is available. Vigorous growth of Isoetes was observed in many ponds.
Luxuriant growth of Isoetes was observed only in environments with stagnant or standing water. However, Isoetes is also observed to along the gentle slope of hillock (Achankulam) where there is no chance for the water to stagnate.

The survival and reestablishment of Isoetes could be to the perennating structures present in the soil or to the spores present in the soil. The uniform growth of Isoetes observed at almost all the ponds at the same time seems to suggest that the growth of Isoetes in each pond could have been due to the perennating structures present there. If this is true, then Isoetes demonstrates a remarkable ability to overcome drought for long periods of time.

This study is a preliminary study aimed at studying the distribution of Isoetes in Tirunelveli district. Further studies on the population structure, population dispersal and genetic relationships of the different populations will give a clearer picture of the nature of Isoetes in Tirunelveli district.

\section{REFERENCES}

Boston, H.L. and M.S. Adams, (1987). Productivity, growth and photosynthesis of two small 'isoëtid' plants, Littorella uniflora and Isoëtes megaspora. J. Ecol. 75: 333-350.

Changkyun Kim, Hye Ryun $\mathrm{Na}$ and Hong-Keun Choi, (2008). Genetic diversity and population structure of endangered Isoetes coreana in South Korea based on RAPD analysis. Aquatic Bot. 89: 43-49.

Fu, L.K. and J.M. Jin, (1992). China plant Red Data Book-rare and endangered plants. Beijing: Science Press, 538-539.

Gacia, E. and E. Ballesteros, (1994). Production of Isoetes lacustris in a Pyrenean lake: seasonality and ecological factors involved in the growing period. Aquatic Bot. 48:77-89.

Keeley, J.E. and G. Busch, (1984). Carbon assimilation characteristics of the aquatic CAM plant Isoëtes howelli. Plant Physiol. 76: 525-530.

Sand-Jensen, K. and M. Søndergaard, (1979). Distribution and quantitative development of aquatic macrophytes in relation to sediment characteristics in oligotrophic Lake Kalgaard, Denmark. Fresh water Biol. 9: 1-11.

Srivastava, G.K., D.D. Pant, and P.K. Shukla, (1993). The genus Isoëtes L. in India. Am. Fern J. 83: 105-119.

Taylor, W.C., N.T. Luebke, D.M. Britton, R.J. Hickey and D.F. Brunton, (1993). Isoetaceae Reichenbach. In: FNA Editorial Committee (Eds.), Flora of North America, Pteridophytes and Gymnosperms, Vol. 2. Oxford University Press, New York, 64-75. 